\title{
EFEKTIVITAS PELAKSANAAN PERDA PENGELOLAAN ZAKAT DI KOTA MOJOKERTO DAN KABUPATEN SIDOARJO
}

\author{
Mhd. Abduh Saf \\ Kantor Hukum "Suhadi dan Partners" JI. Imam Bonjol No. I 4 E Blitar Jawa Timur | \\ mhdabduh34@yahoo.co.id
}

\begin{abstract}
Currently, local regulations on zakat (Islamic obligatory charity) management has been set up in many regions in Indonesia. InMojokerto and Sidoarjo regency, such local regulations are expected to be effective for improving the welfare of the society. This local zakat management that has the role to collect and distribute zakat is called BAZ (BadanAmil Zakat). It seems that the zakat management in Mojokerto and Sidoarjo is more effective under the present of such a local regulation. It can be seen from the increase number of the charity payers, the increase of $B A Z \mathrm{~s}$ charity programs, and the operation costs charged to APBD (Regional Government Budget). If it is analyzed by the effectiveness legal theory, it can be concluded that the observance of a rule of law (the perda or local regulation on the charity management) in Mojokerto and Sidoarjo regency is a kind of the internalizational obedience. It is because such observance of a rule of law is in accordance with the intrinsic values adopted. In addition, such local regulations are obeyed because giving charity is one of the fundamental Islamic teachings. The values embodied in charity in Islam have a very clear purpose, benefit, and punishment in the world and in the hereafter. These Islamic values contribute dearly to the success of the application of this local regulation on the charity management. Keywords: Charity management, local regulation, effectiveness, and $B A Z$.
\end{abstract}

Abstrak: Saat ini zakat telah diatur dalam bentuk suatu Peraturan Daerah seperti Peraturan Daerah tentang Pengelolaan Zakat di Kota Mojokerto dan Kabupaten Sidoarjo. Dengan adanya Perda tersebut, diharapkan efektif untuk meningkatkan kesejahteraan masyarakat khususnya di Kota Mojokerto dan Kabupaten Sidoarjo. Perkembangan pengelolaan zakat pada BAZ di Kota Mojokerto dan Kabupaten 
Sidoarjo dengan adanya Perda tentang pengelolaan zakat menjadi lebih efektif. Hal itu bisa dilihat dari bertambahnya jumlah mudhakki, peningkatan perolehan dana zakat serta biaya operasional BAZ yang dibebankan kepada APBD. Apabila dianalisis dengan teori efektivitas hukum, maka bisa diambil kesimpulan bahwa ketaatan terhadap suatu aturan hukum (dalam hal ini adalah Perda tentang Pengelolaan zakat) di Kota Mojokerto dan Kabupaten Sidoarjo bersifat ketaatan internalization, yakni suatu peraturan ditaati karena merasa aturan itu sesuai dengan nilai-nilai intrinsik yang dianut. Perda tentang pengelolaan zakat ditaati karena menunaikan zakat merupakan ajaran Islam. Nilai-nilai yang terkandung dalam ajaran Islam mengenai zakat sangat jelas baik tujuan, manfaat serta sanksi baik di dunia maupun di akhirat. Nilai-nilai inilah yang menjadi dasar dalam menaati Perda tentang Pengelolaan Zakat yang sesuai dengan ajaran Islam.

Kata Kunci: Pengelolaan zakat, Perda, efektivitas dan BAZ

\section{Pendahuluan}

Dengan munculnya Undang-Undang Nomor 22 Tahun 1999 tentang Pemerintahan Daerah yang sekarang telah diamandemen menjadi Undang-Undang Nomor 34 Tahun 2004, telah memberikan peluang kepada Pemerintah Daerah untuk lebih mengatur dan mengurus sendiri urusan pemerintahan di daerah masing-masing dengan harapan dapat mempercepat terwujudnya kesejahteraan masyarakat melalui peningkatan, pelayanan, pemberdayaan dan peran serta masyarakat. Sebagaimana yang terdapat di dalam Pasal 1 ayat 5 Undang-Undang Nomor 34 Tahun 2004 tentang Pemerintahan Daerah menyatakan bahwa otonomi daerah adalah hak, wewenang dan kewajiban daerah otonom untuk mengatur dan mengurus sendiri urusan pemerintahan dan kepentingan masyarakat setempat sesuai dengan peraturan perundang-undangan. ${ }^{1}$

Indonesia sendiri dikenal dengan negara Hukum yang mana segala sesuatunya diatur dan diproses sesuai dengan Hukum yang

\footnotetext{
' Undang-Undang Republik Indonesia nomor 32 Tahun 2004 tentang Pemerintahan Daerah (Pasal I ayat 5), 4 .
} 
ada (Hukum yang telah diundangkan oleh penguasa) ${ }^{2}$. Begitu pun juga dalam mengatur bidang agama, diperlukan peran negara demi menjamin kehidupan beragama yang diharapkan. Segala hal yang berkaitan dengan agama, terutama agama Islam baik mengenai perkawinan, zakat, wakaf, haji, waris dan lain sebagainya, telah diatur di dalam Undang-Undang, peraturan pemerintah, ataupun keputusan menteri. Sampai sejauh ini, negara telah banyak mengakomodasi kepentingan umat Islam dalam struktur kenegaraan.

Sebagaimana halnya dalam pengelolaan zakat, negara telah mengaturnya dalam Undang-Undang 38 Tahun 1999 tentang Pengelolaan Zakat yang kemudian diamandemen menjadi Undang-Undang Nomor 23 Tahun 2011. Tidak hanya itu, kini dengan munculnya Undang-Undang Nomor 22 Tahun 1999 tentang Pemerintahan Daerah yang sekarang telah diamandemen menjadi Undang-Undang Nomor 34 Tahun 2004, pemerintah telah memberikan peluang kepada Pemerintah Daerah (Pemda) untuk dapat mengatur dan mengurus sendiri urusan pemerintahan di daerah masing-masing, sehingga Pemda menjadikan momen ini untuk membentuk peraturan daerah (Perda) sesuai dengan kebutuhan di Pemda tersebut.

Begitu halnya dengan Pemda yang terdapat di Provinsi Jawa Timur, terdapat tiga Kota/ Kabupaten yang telah memiliki Perda tentang Pengelolaan Zakat, yakni Kota Mojokerto, Kabupaten Sidoarjo dan Kabupaten Bondowoso. Ketiga Kabupaten ini telah membentuk Perda tentang Pengelolaan Zakat. Suatu hal yang sangat perlu diapresiasi karena di Provinsi Jawa Timur, hanya ketiga Kabupaten tersebut yang membentuk Perda tersebut. Padahal di Kabupaten dan Kota lain di Provinsi Jawa Timur banyak terdapat badan dan lembaga zakat (juga mengelola infaq

${ }^{2}$ Masykuri Abdillah, Formalisasi Syariat Islam di Indonesia, (Ciputat: Renaisan, 2005), 92. 
dan shodaqoh) namun tidak sampai membentuk Perda tentang Pengelolaan Zakat. ${ }^{3}$

Mengenai Pengelolaan Zakat di Kabupaten Mojokerto diatur dalam Peraturan Daerah Kota Mojokerto Nomor 1 Tahun 2003 yang kemudian diamandemen menjadi Perda Nomor 3 Tahun 2010 tentang Pengelolaan Zakat. Sedangkan untuk Kabupaten Sidoarjo diatur dalam Peraturan Daerah Kabupaten Sidoarjo Nomor 4 Tahun 2005.

Sebagaimana terlihat tujuan masing-masing Perda tersebut yang senada dengan tujuan dari Undang-Undang Nomor 23 Tahun 2011 Tentang Pengelolaan Zakat, yakni secara komprehensif bertujuan untuk memperbaiki serta meningkatkan kesejahteraan masyarakat dan menanggulangi kemiskinan melalui zakat dengan pengelolaan yang baik. Memang, kemiskinan adalah masalah yang amat mendasar baik disebabkan oleh keterbelakangan lapangan kerja, pendapatan, pendidikan dan kesehatan masyarakat. ${ }^{4}$

Pernyataan zakat tidak mampu mengentaskan kemiskinan dengan alasan orang miskin (mustahiq) lebih banyak dari pada orang kaya (mudhakki) $)^{5}$ maka hal itu tidak sepenuhnya salah, juga tidak sepenuhnya benar. Melihat kondisi masyarakat di daerahdaerah miskin, para pengemis, pengumpul dana sosial di jalanjalan dengan alasan untuk pembangunan sekolah dan masjid yang mayoritas juga orang Islam, maka pengentasan kemiskinan akan terasa sulit. ${ }^{6}$ Tapi jika dana zakat dikelola dengan baik maka tidak mustahil kemiskinan dapat dituntaskan. Zakat merupakan salah satu instrumental dalam mengentaskan kemiskinan. Dana zakat

${ }^{3}$ Dari data mengenai Perda Zakat yang dikumpulkan, diperoleh Total Sebanyak 44 perda zakat yang tersebar di 13 Provinsi dan 43 kota Kabupaten. 3 di antaranya terdapat di Provinsi Jawa Timur, yakni Kota Mojokerto, Kabupaten Sidoarjo dan Kabupaten Bondowoso.

${ }^{4}$ Muhammad Ridwan Mas'ud, Zakat \& Kemiskian, Instrumen Pemberdayaan Ekonomi Umat, (Yogyakarta: UII Press Yogyakarta, 2005), 89.

${ }^{5}$ Kalimat ini dikutip dari seminar Syafii Antonio dengan tema "Bagaimana Meraih Sukses dalam hidup dan bisnis", Surabaya 22 Desember 2012.

${ }^{6}$ Muhammad Abdul Malik ar-Rahman, Zakat, 1001 Masalah dan Solusinya, (Jakarta: Pustaka Cerdas Zakat, 2003), 168. 
yang dikelola dengan sistem dan manajemen yang amanah, profesional dan integral dengan bimbingan dan pengawasan dari pemerintah dan masyarakat akan menjadi pemacu gerak ekonomi di dalam masyarakat dan menyehatkan tatanan sosial sehingga semakin berkurangnya kesenjangan antara kelompok masyarakat yang miskin dan kaya. ${ }^{7}$

\section{Pembahasan}

Zakat telah diatur dalam dua undang-undang yaitu UndangUndang Nomor 38 Tahun 1999 dan Undang-Undang Nomor 23 Tahun 2011. Selain diatur dalam undang-undang, zakat juga telah diatur dalam Peraturan Daerah. Hal yang mendasari lahirnya Perda tentang Pengelolaan Zakat tersebut adalah sebagai berikut. Pertama, Pasal 1 ayat 5 Undang-Undang Nomor 32 Tahun 2004 tentang Pemerintahan Daerah yang menyatakan bahwa otonomi daerah adalah hak, wewenang dan kewajiban daerah otonom untuk mengatur dan mengurus sendiri urusan pemerintahan dan kepentingan masyarakat setempat sesuai dengan peraturan perundang-undangan. ${ }^{8}$ Kedua, Dibentuknya Perda adalah dalam rangka penyelenggaraan otonomi daerah baik provinsi ataupun Kabupaten. ${ }^{9}$ Dengan munculnya Undang-Undang Nomor 32 Tahun 2004 tentang Pemerintahan Daerah di atas merupakan awal dari terlaksananya berbagai penerapan peraturan di daerah pemerintahan masing-masing sehingga Pemerintah Daerah menjadikan momen ini untuk membentuk peraturan daerah (perda) sesuai dengan kebutuhan di Pemda tersebut, begitu juga dengan perda tentang zakat. Ketiga, Fungsi Peraturan Daerah yakni dapat menyelenggarakan peraturan yang belum diatur oleh Peraturan Daerah yang lebih tinggi. ${ }^{10}$

7 Umrotul Khasanah, Manajemen Zakat Modern, Instrumen Pemberdayaan Ekonomi Umat, (Malang: UIN- Maliki Press, 2010), 39.

${ }^{8}$ Pasal I ayat 5 Undang-Undang Nomor 32 Tahun 2004 tentang Pemerintahan Daerah.

${ }^{9}$ lbid.

10 Maria Farida Indrati Soeprapto, IImu Perundang-Undangan, Dasar-Dasar dan Pembentukannya, (Yogyakarta: Penerbit Kanisius, 1998), 121. Peraturan Daerah dalam hal ini adalah Peraturan 


\section{Pengelolaan Zakat dalam Perda Kota Mojokerto dan Kabupaten Sidoarjo}

Selain mengelola zakat, Perda di Kota Mojokerto dan Perda di Kabupaten Sidoarjo juga mengatur tentang pengelolaan infaq dan shodaqoh, bahkan pengelolaannya menyatu dan tidak dipisahkan dengan pengelolaan zakat, sehingga nama peraturan daerahnya dinamakan dengan Perda tentang Pengelolaan Zakat, Infaq dan Shadaqah. Berbeda dengan undang-undang zakat yang tidak mencantumkan kata infaq dan shadaqah di dalam nama undang-undang tersebut (baik undang-undang yang lama ataupun yang baru). Hal ini bukan berarti Undang-undang Zakat tidak mengatur tentang infaq dan shadaqah.

UU Nomor 38 Tahun 1999 tentang Pengelolaan Zakat, awalnya dalam penjelasan dijelaskan bahwa Undang-undang tentang Pengelolaan Zakat juga mencakup pengelolaan infaq, shadaqah, wasiat, waris, hibah dan kafarat dengan perencanaan, pengorganisasian, pelaksanaan dan pengawasan agar menjadi pedoman bagi mudhakki dan mustahiq, baik perseorangan maupun badan hukum dan/atau badan usaha. Sedangkan dalam UU Nomor 23 Tahun 2011 tentang Pengelolaan Zakat (amandemen dari dari UU Nomor 38 Tahun 1999 tentang Pengelolaan Zakat) juga mengatur tentang infaq dan shadaqah, walaupun pengelolaannya dibedakan dengan zakat. Pengelolaan infaq dan shadaqah harus dicatat dalam pembukuan tersendiri. ${ }^{11}$

Terkait dengan Perda Zakat di Kota Mojokerto dan Kabupaten Sidoarjo, maka pengelolaan zakat (juga infaq dan shodaqoh) di Kabupaten Mojokerto diatur dalam Peraturan Daerah Kota Mojokerto Nomor 1 Tahun 2003 yang kemudian

Daerah Kota Mojokerto dan Kabupaten Sidoarjo. Peraturan Daerah yang lebih tinggi dalam hal ini adalah Peraturan Daerah Provinsi Jawa Timur. Dari daftar Perda zakat di atas, terlihat bahwa Provinsi Jawa Timur belum memiliki Perda tentang zakat. Jadi Pemerintah Daerah di tingkat Kabupaten dan Kota (Sidoarjo dan Mojokerto) sudah sewajarnya membentuk Perda tentang zakat sebagai bentuk penyelenggaraan peraturan yang belum diatur oleh Pemerintah Daerah Provinsi Jawa Timur.

" Pasal 28 ayat (3) Undang-Undang Nomor 23 Tahun 20 I I tentang Pengelolaan Zakat.

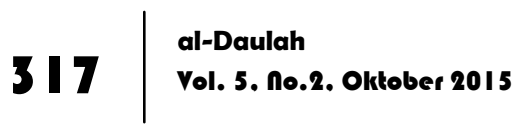


diamandemen menjadi Perda Nomor 3 Tahun 2010 tentang Pengelolaan Zakat, Infaq dan Shodaqoh. ${ }^{12}$ Sebelum diamandemen, Peraturan Daerah Kota Mojokerto Nomor 1 Tahun 2003 ini terdiri dari 9 Bab dan 27 Pasal. Setelah diamandemen menjadi Perda Nomor 3 Tahun 2010 tentang Pengelolaan Zakat, Infaq dan Shodaqoh, terdiri dari 9 Bab dan 28 Pasal.

Bab yang diamandemen terdapat pada Bab IX, yakni penambahan Pasal 26 mengenai pernyataan tidak berlakunya Peraturan Daerah Kota Mojokerto Nomor 1 Tahun 2003 dan ada beberapa perubahan aturan pada beberapa bab lainnya yang dianggap perlu sebagai penyesuaian. Adapun penyempurnaan atas Peraturan Daerah Nomor 1 Tahun 2003 tentang Zakat, Infaq dan Shodaqoh menjadi Peraturan Daerah Nomor 3 tahun 2010 terdapat pada judul Perda, klausul menimbang, pasal 5, 15, 16, 17, 18, 19, 20, 22 dan pasal 23.13

Berdasarkan Naskah Akademik RANPERDA ZIS Kota Mojokerto Tahun 2010, Perda Kota Mojokerto Nomor 1 Tahun 2003 sudah tidak efektif lagi. Terdapat dua hal yang mendasari mengapa Perda yang lama tidak sesuai lagi dan dicabut. Pertama, pada pasal 20 Perda Nomor 1 Tahun 2003 tentang sasaran pendayagunaan ZIS. Pada pasal 20 ini dijelaskan bahwa sasaran pendayagunaan ZIS diberikan kepada delapan asnaf yang meliputi bea Siswa bagi anak fakir dan miskin, panti asuhan, bantuan kesehatan bagi fakir miskin, sarana ibadah dan pendidikan, modal kerja bagi golongan ekonomi lemah dan untuk bantuan da'i. Padahal secara syariat ada perbedaan yang mendasar antara ketentuan zakat dengan infaq/shodaqoh, khususnya tentang jenis, jumlah, waktu dan sasaran pendayagunaannya. Oleh karena itu, dirasa perlu adanya revisi/penyesuaian pada Perda yang baru. Kedua, sudah 7 tahun berlalu sejak Perda yang lama disahkan, maka atas dasar pertimbangan ekonomi, perkembangan nilai mata

${ }^{12}$ Ditetapkan di Mojokerto pada tanggal I I Oktober 20 I 0 dan diundangkan pada tanggal 2 Maret 20I I di Kota Mojokerto.

${ }^{13}$ Naskah Akademik RANPERDA ZIS Kota Mojokerto, 1 8-26. 
uang rupiah dan kenaikan gaji pegawai khususnya tentang besarnya nilai infaq dan shodaqoh, maka Pemerintah Kota Mojokerto merasa perlu adanya penyempurnaan dengan mencabut Perda Nomor 1 Tahun 2003 tentang Zakat, Infaq dan Shodaqoh dan menetapkan Perda yang baru. ${ }^{14}$ Di samping itu juga diperlukan adanya revisi tentang pendayagunaan ZIS. Maka demi efektifnya suatu peraturan perundang-undangan maka lahirlah Perda Nomor 3 Tahun 2010 tentang Pengelolaan Zakat, Infaq dan Shodaqoh.

Sedangkan untuk Kabupaten Sidoarjo diatur lewat Peraturan Daerah Kabupaten Sidoarjo Nomor 4 Tahun 2005. ${ }^{15}$ Perda ini terdiri dari 10 bab dan 26 Pasal. Tidak jauh berbeda dengan pengelolaan zakat yang terdapat dalam Peraturan Daerah Kota Mojokerto, pengelolaan zakat dalam Peraturan Daerah Kabupaten Sidoarjo secara garis besar hampir sama dan hanya terdapat sedikit perbedaan dengan pengelolaan zakat Kota Mojokerto. Hal itu bisa dilihat dari persamaan pengertian, landasan, asas serta tujuan pengelolaan zakat. Begitu juga dengan unsur-unsur pada organisasi, tata kerja, obyek, ketentuan, pendayagunaan dan pelaporan, pembiayaan dan pengawasan serta ketentuan pidana pengelolaan zakat yang hanya memiliki sedikit perbedaan seperti perbedaan penggunaan nama istilah dan beberapa unsur lainnya.

Selanjutnya, bila dibandingkan ketentuan pengelolaan zakat Kabupaten Sidoarjo dengan Kota Mojokerto, maka perbedaannya adalah sebagai berikut:

${ }^{14} \mathrm{Ibid} ., 18$.

${ }^{15}$ Ditetapkan tanggal 16 April 2005 dan diundangkan tanggal 17 April tahun 2005 di Kabupaten Sidoarjo. 
Perbandingan Perda Pengelolaan Zakat

Kota Mojokerto dan Kabupaten Sidoarjo ${ }^{16}$

\begin{tabular}{|c|c|c|c|}
\hline \multirow[b]{2}{*}{ No } & \multirow{2}{*}{$\begin{array}{c}\text { Unsur } \\
\text { Pengelolaan } \\
\text { Zakat } \\
\end{array}$} & \multicolumn{2}{|c|}{ Perda Zakat } \\
\hline & & Kota Mojokerto & Kabupaten Sidoarjo \\
\hline 1 & $\begin{array}{l}\text { Organisasi } \\
\text { Pengelola }\end{array}$ & BAZ dan UPZ & BAZ, LAZ dan UPZ \\
\hline 2 & Wilayah kerja & $\begin{array}{l}\text { Disebutkan secara jelas } \\
\text { dalam bentuk ayat yakni } \\
\text { seluruh wilayah } \\
\text { administratif } \\
\text { Pemerintah Kota } \\
\text { Mojokerto }\end{array}$ & $\begin{array}{l}\text { Tidak disebutkan } \\
\text { secara jelas dalam } \\
\text { bentuk ayat }\end{array}$ \\
\hline 3 & Obyek zakat & $\begin{array}{l}\text { Menyebutkan uang dan } \\
\text { hasil peternakan sebagai } \\
\text { salah dua jenis harta } \\
\text { yang dikenai zakat mal }\end{array}$ & $\begin{array}{l}\text { Tidak menyebutkan } \\
\text { uang dan hasil } \\
\text { peternakan sebagai } \\
\text { jenis harta yang } \\
\text { dikenai zakat mal }\end{array}$ \\
\hline 4 & $\begin{array}{l}\text { Hubungan kerja } \\
\text { sama }\end{array}$ & $\begin{array}{l}\text { Tidak ada pernyataan } \\
\text { hubungan kerja sama } \\
\text { dalam pengumpulan } \\
\text { zakat dengan pihak lain }\end{array}$ & $\begin{array}{l}\text { Terdapat pernyataan } \\
\text { hubungan kerja sama } \\
\text { dalam pengumpulan } \\
\text { zakat dengan Bank, } \\
\text { Koperasi dan LKBB }\end{array}$ \\
\hline 5 & $\begin{array}{l}\text { Pendayagunaan } \\
\text { zakat }\end{array}$ & $\begin{array}{l}\text { Selain kepada delapan } \\
\text { asnaf, pendayagunaan } \\
\text { zakat dalam aplikasinya } \\
\text { dapat meliputi bantuan } \\
\text { pendidikan anak fakir } \\
\text { miskin, bantuan } \\
\text { kesehatan fakir miskin, } \\
\text { panti-panti asuhan anak } \\
\text { yatim, sarana } \\
\text { peribadatan dan } \\
\text { pendidikan, kegiatan } \\
\text { dakwah dan sosial }\end{array}$ & $\begin{array}{l}\text { Diberikan kepada } \\
\text { delapan asnaf namun } \\
\text { tidak menjelaskan } \\
\text { lebih lanjut } \\
\text { pengaplikasian } \\
\text { pendayagunaan zakat }\end{array}$ \\
\hline
\end{tabular}

${ }^{16}$ Selain perbedaan unsur pengelolaan zakat di atas, maka selebihnya pengelolaan zakat antara kedua perda tersebut adalah sama. 


\begin{tabular}{|c|l|l|l|}
\hline & & $\begin{array}{l}\text { keagamaan, orang } \\
\text { jompo, penyandang } \\
\text { cacat, anak terlantar, dan } \\
\text { korban bencana alam }\end{array}$ & \\
\hline 6 & $\begin{array}{l}\text { Biaya } \\
\text { Operasional } \\
\text { BAZ }\end{array}$ & $\begin{array}{l}\text { BAZ mendapat 7,5\% } \\
\text { dari ZIS yang terkumpul } \\
\text { dan UPZ mendapat 5\% } \\
\text { dari ZIS yang terkumpul }\end{array}$ & $\begin{array}{l}\text { BAZ mendapat 5\% } \\
\text { dari ZIS yang } \\
\text { terkumpul dan UPZ } \\
\text { mendapat 5\% dari ZIS } \\
\text { yang terkumpul }\end{array}$ \\
\hline 7 & $\begin{array}{l}\text { Ketentuan } \\
\text { pidana }\end{array}$ & $\begin{array}{l}\text { Tindak pidana yang } \\
\text { dimaksud dalam bab } \\
\text { tentang ketentuan } \\
\text { pidana adalah tindak } \\
\text { pidana berupa } \\
\text { pelanggaran. }\end{array}$ & $\begin{array}{l}\text { Tidak menyebutkan } \\
\text { jenis tindak pidana } \\
\text { (kesalahan atau } \\
\text { pelanggaran) dalam } \\
\text { bab tentang ketentuan } \\
\text { pidana }\end{array}$ \\
\hline 8 & Sanksi pidana & $\begin{array}{l}\text { Kurungan selama- } \\
\text { lamanya 3 (tiga) bulan } \\
\text { atau denda sebanyak- } \\
\text { banyaknya Rp } \\
\text { 30.000.000,00 (tiga puluh } \\
\text { juta rupiah) }\end{array}$ & $\begin{array}{l}\text { Tidak mengatur } \\
\text { sanksi tindak pidana } \\
\text { baik kurungan } \\
\text { ataupun denda }\end{array}$ \\
\hline
\end{tabular}

\section{Regulasi dan Efektivitas dalam Perda tentang Pengelolaan Zakat}

Bagaimana pun juga, pemerintah hanya berperan sebagai regulator dalam hal pengelolaan zakat dan berperan sebagai fasilitator bagi organisasi atau lembaga yang menjalankan pengelolaan zakat dan tidak berperan sebagai operator. Oleh karena itu, pemerintah hanya memiliki peran dalam membuat peraturan perundang-undangan sesuai dengan perannya sebagai regulator dan fasilitator. Walaupun demikian, dengan adanya Perda ini maka akan menimbulkan kekuatan hukum dalam setiap regulasinya. ${ }^{17}$

17 Pasal I ayat (2) Undang-undang Nomor 12 Tahun 201 I tentang pembentukan peraturan perundang-undangan. 
Mengawali analisis Perda tentang Pengelolaan Zakat, maka terlebih dahulu diperhatikan apakah Perda yang ada sekarang ini sudah berjalan harmonis dengan peraturan perundang-undangan terkait Perda ini. Diawali dengan Undang-Undang tentang pengelolaan zakat yang telah diamandemen menjadi Undangundang Nomor 23 Tahun 2011 tentang Pengelolaan Zakat. Secara penetapan peraturan perundang-undangan, memang Perda tentang Pengelolaan Zakat di Kota Mojokerto dan Kabupaten Sidoarjo lebih dahulu lahir dan ditetapkan sehingga masih menggunakan Undang-Undang pengelolaan zakat yang lama yakni Nomor 38 Tahun 1999 sebagai salah satu unsur "mengingat" di dalam Perdanya, padahal undang-undang pengelolaan zakat tersebut sudah diamandemen. Namun Perda tentang pengelolaan zakat di Kota Mojokerto dan Kabupaten Sidoarjo masih tetap berlaku karena dua alasan. Pertama, karena di dalam Pasal 44 Undang-undang Nomor 23 Tahun 2011 tentang Pengelolaan Zakat dinyatakan bahwa semua Peraturan perundang-undangan tentang Pengelolaan Zakat dinyatakan masih berlaku selama tidak bertentangan dengan ketentuan dalam Undang-undang Nomor 23 Tahun 2011 tentang Pengelolaan Zakat ini. Kedua, Undangundang Nomor 23 Tahun 2011 tentang Pengelolaan Zakat sendiri belum memiliki PP, sehingga PP Undang-undang Nomor 38 Tahun 1999 masih tetap berlaku. Jadi, secara yuridis, Perda di Kota Mojokerto dan Kabupaten Sidoarjo masih berlaku efektif dan memiliki kekuatan hukum yang mengikat.

\section{Perkembangan Pengelolaan Zakat di BAZ Kota Mojokerto dan Kabupaten Sidoarjo dengan adanya Perda tentang Pengelolaan Zakat}

Sebelum adanya Perda tentang pengelolaan zakat yang baru di Kota Mojokerto, sasaran pendayagunaan zakat kepada delapan asnaf belum sesuai dengan ketentuan syariat Islam dan masih menyatu pendayagunaannya dengan infaq dan shodaqoh. Di dalam Perda yang lama, pendayagunaan zakat, infaq dan 
shodaqoh berupa beasiswa bagi fakir miskin, panti asuhan, bantuan kesehatan bagi fakir miskin, sarana peribadatan dan pendidikan, modal kerja bagi golongan ekonomi lemah serta bantuan untuk da'i. Namun, setelah adanya Perda yang baru, ketentuan pendayagunaan zakat dibedakan dengan infaq dan shodaqoh. Zakat diberikan kepada delapan asnaf yakni fakir, miskin, amil, muallaf, riqab, gharim, sabilillah dan ibnu sabil. ${ }^{18}$ Sedangkan pendayagunaan infaq dan shodaqoh untuk kesejahteraan umum dengan prioritas utama untuk pemberdayaan ekonomi kaum dhuafa. Oleh karena itu, BAZ dalam pendayagunaan zakat kini sesuai dengan syariat Islam.

Adapun perkembangan BAZ Kota Mojokerto dengan adanya Perda tentang pengelolaan zakat, bisa dilihat dalam beberapa aspek berikut :

a. Peningkatan jumlah mudhakki dari PNS.

Jumlah mudhakki yang dikelola BAZ Kota Mojokerto meningkat drastis. Jika pada tahun 2009 bisa dikatakan BAZ tidak memiliki mudhakki tetap, maka pada akhir tahun 2010, telah tercatat sebanyak 616 mudhakki menyalurkan zakatnya melalui BAZ Mojokerto. Jumlah mudhakki tersebut mengalami kenaikan hingga pada akhir Triwulan 1 tahun 2011, dimana BAZ telah memiliki sekitar 783 mudhakki.

Pada tahun 2011, jumlah mudhakki berkembang menjadi 920 orang. Dari 920 mudhakki tersebut, sebanyak 73 \% berasal dari kalangan PNS baik pegawai Pemkot maupun instansi vertikal yang ada di Kota Mojokerto. Mudhakki dari masyarakat umum non PNS masih relatif kecil jumlahnya yaitu hanya sekitar $17 \%$.

Sedangkan pada tahun 2012, jumlah mudhakki kembali didominasi para PNS. Jumlah mudhakki dari PNS mengalami kenaikan yang sangat signifikan yakni sebesar $36 \%$, sedangkan mudhakki dari segmentasi masyarakat pada tahun

\footnotetext{
${ }^{18}$ Naskah Akademik RANPERDA ZIS Kota Mojokerto, 20 I 0, 25.
}

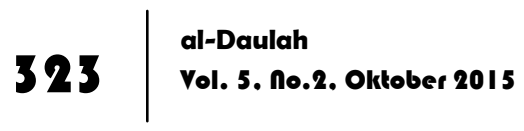


2012 hanya mengalami kenaikan sebesar $5 \%$. Peningkatan jumlah mudhakki dari kalangan PNS karena adanya pemberlakuan Perda Nomor 3 tahun 2010 tentang pengelolaan zakat, infaq dan shodaqoh serta peraturan Walikota Mojokerto nomor 54 Tahun 2009 tentang Pedoman Teknis Pemungutan Zakat Pendapatan, Infaq dan Shodaqoh bagi PNS, karyawan BUMD/BUMN, anggota DPRD dan warga masyarakat Kota Mojokerto.

b. Biaya Operasional BAZ

Sebagaimana terdapat pada Pasal 22 Perda Nomor 3 Tahun 2010 tentang Pengelolaan Zakat di Kota Mojokerto bahwa biaya operasional BAZ Kota Mojokerto dibebankan pada Anggaran dan Pendapatan dan Belanja Daerah Kota Mojokerto sesuai dengan kemampuan keuangan daerah. Dengan adanya Perda ini, BAZ Kota Mojokerto lebih bisa menghemat dana ZIS dan lebih difokuskan kepada yang berhak menerimanya. Jadi, APBD digunakan untuk menjalankan Program Kerja BAZ Kota Mojokerto yang merupakan bentuk dari biaya operasional BAZ.

Sama halnya dengan perkembangan BAZ Kota Mojokerto, BAZ Kabupaten Sidoarjo juga mengalami perkembangan dengan adanya Perda Nomor Tahun 2005 tentang Pengelolaan Zakat. Setidaknya ada dua hal yang membedakan BAZ Kabupaten Sidoarjo baik sebelum dan sesudah adanya Perda tentang Pengelolaan Zakat :

a. Perolehan ZIS

Perda tentang Pengelolaan Zakat di Kabupaten Sidoarjo berlaku mulai tanggal 16 April 2005. Sebelum Perda tentang Pengelolaan Zakat ini ada, perolehan dana ZIS masih tidak stabil (fluktuatif) setiap tahunnya yakni semenjak tahun 2001 s/d 2005. Hal tersebut bisa dilihat dari pengumpulan serta pendistribusian dana ZIS BAZ Kabupaten Sidoarjo. Setelah adanya Perda tentang Pengelola Zakat, pada tanggal 16 April 
tahun 2005, perolehan dana ZIS mengalami peningkatan setiap tahunnya hingga tahun 2102, dimana dana yang diperoleh sebesar Rp 1.023.931.661 (satu miliar dua puluh tiga juta sembilan ratus tiga puluh satu ribu enam ratus enam puluh satu rupiah). Nominal ini adalah nominal terbesar yang diperoleh BAZ Kabupaten Sidoarjo. Jadi dapat disimpulkan bahwa dengan adanya Perda tentang Pengelolaan Zakat, menjadikan pengumpulan zakat lebih efektif, apa lagi pengutipan zakat dari PNS di setiap instansi pemerintahan menjadi lebih mudah dengan adanya Perda tentang Pengelolaan Zakat ini. ${ }^{19}$

b. Biaya Operasional BAZ Kabupaten Sidoarjo

Sebelum adanya Perda tentang Pengelolaan Zakat di Kabupaten Sidoarjo, biaya operasional BAZ masih menggunakan dana dari BAZ. Sebagaimana tertulis di dalam laporan keuangan \& uraian kegiatan BAZ Kabupaten Sidoarjo dari tahun 2001 s/d 2012, 5 tahun pertama dana operasional BAZ diambil dan dikeluarkan dari dana BAZ. Sedangkan semenjak tahun 2007, biaya operasional BAZ sudah dipisahkan dan dibebankan kepada APBD. ${ }^{20}$

\section{Tingkat efektivitas Pelaksanaan Perda Tentang Pengelolaan Zakat}

Sebagaimana teori efektivitas yang disampaikan oleh Achmad Ali bahwa tolak ukur efektivitas dilihat dari sejauh mana aturan hukum itu ditaati atau tidak ditaati. Jika suatu aturan hukum ditaati oleh sebagian besar target sasaran ketaatannya, maka aturan hukum tersebut bersifat efektif dan begitu pula sebaliknya. Adapun tolak ukur keefektifan (derajat efektivitas) suatu

\footnotetext{
${ }^{19}$ Abdul Hakim, Wawancara, Sidoarjo, 7 Mei 2013.

20 Pasal 21 Peraturan Daerah Nomor 4 Tahun 2005 tentang Pengelolaan Zakat di Kabupaten Sidoarjo.
} 
peraturan hukum tergantung pada kualitas ketaatan menurut H.C Kelman ada tiga bentuk ketaatan, ${ }^{21}$ yaitu :

a. Ketaatan yang bersifat compliance, yaitu menaati suatu peraturan karena ada unsur takut terhadap sanksi. Ketaatan semacam ini tergolong ketaatan yang lemah karena membutuhkan pengawasan yang terus menerus.

b. Ketaatan yang bersifat identification, yaitu menaati suatu peraturan karena takut hubungan baik (good relation) dengan pihak lain menjadi rusak.

c. Ketaatan yang bersifat internalization, yaitu menaati suatu peraturan karena merasa bahwa aturan itu sesuai dengan nilai-nilai intrinsik (inti) yang dianut.

Jadi, dengan mengetahui adanya tiga jenis ketaatan tersebut maka bisa dibedakan kualitas efektivitasnya suatu aturan hukum. Semakin banyak warga masyarakat yang menaati suatu aturan hukum atau perundang-undangan hanya dengan ketaatan yang bersifat compliance atau identification saja, berarti derajat serta kualitas keefektifan menaati hukum masih rendah. Sedangkan jika semakin banyak warga masyarakat yang ketaatannya bersifat internalization maka semakin tinggi kualitas efektivitas aturan hukum atau perundang-undangan itu.

Jika diperhatikan jumlah mudhakki serta perolehan dana ZIS baik pada BAZ Kota Mojokerto serta Kabupaten Sidoarjo yang mengalami peningkatan setelah berlakunya Perda tentang pengelolaan zakat, maka hal itu menunjukkan bahwa adanya suatu unsur ketaatan dari para mustahiq, munfiq dan mutashodiq terhadap Perda tersebut. Tentunya hal ini tidak terlepas dari upaya BAZ yang diamanahkan untuk mengelola tugas tersebut.

Adapun bentuk tingkat atau kualitas ketaatan di sini adalah ketaatan yang bersifat internalization, yaitu menaati suatu peraturan karena merasa bahwa aturan itu sesuai dengan nilai-

${ }^{21}$ Achmad Ali, Menguak Teori Hukum (Legal Theory) dan Teori Peradilan (Judicialprudence), (Jakarta: Prenada Media Group, 2009), 348. 
nilai intrinsik (inti) yang dianut. ${ }^{22}$ Karena pada hakikatnya, tanpa adanya Perda pun, umat Islam bisa memahami dan dapat menerima bahwa menunaikan zakat merupakan salah satu kewajibannya sebagai umat Islam. Sebagaimana yang terdapat di dalam hadis berikut :

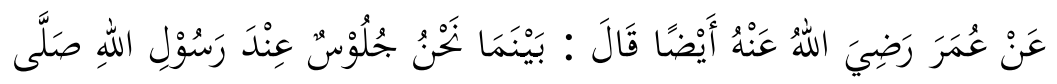

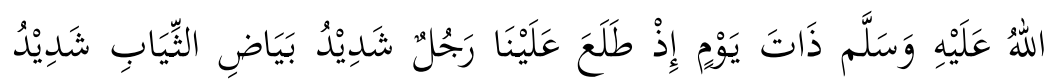

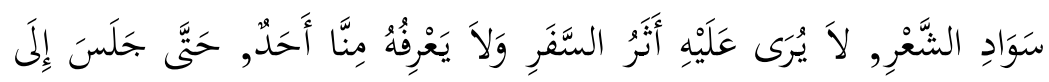

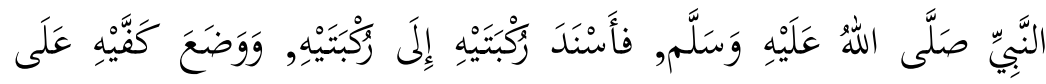

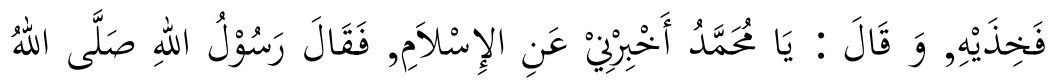

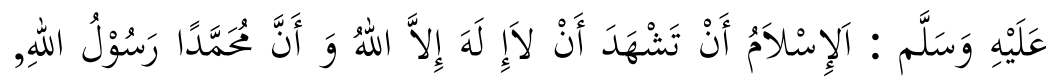

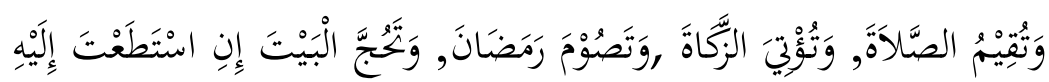

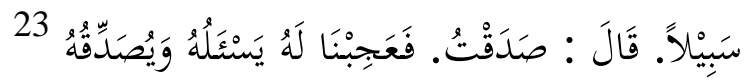
"'Umar bin al-Khattab R.A "Suatu ketika, kami duduk di dekat Rasulullah SAW. Tiba-tiba muncul kepada kami seorang lelaki mengenakan pakaian yang sangat putih dan rambutnya amat hitam. Tak terlihat padanya tanda-tanda bekas perjalanan, dan tak ada seorang pun di antara kami yang mengenalnya. Ia segera duduk di hadapan Nabi lalu lututnya disandarkan kepada lutut Nabi dan meletakkan kedua tangannya di atas kedua paha Nabi, kemudian ia berkata: "Hai, Muhammad, beritahukan kepadaku tentang Islam." Rasulullah menjawab, "Islam adalah, engkau bersaksi tidak ada yang berhak disembah dengan benar melainkan hanya Allah, dan sesungguhnya Muhammad adalah utusan Allah, menegakkan shalat, menunaikan zakat, berpuasa di bulan Ramadhan dan engkau

\footnotetext{
${ }_{22}^{22}$ Achmad Ali, Menguak Teori Hukum, 348.

${ }^{23}$ Imam Abu al-Husain Muslim bin al-Hajjaj al-Qushairiy al-Naisaburiy, Sahih al-Muslim, (Beirut: Dar al-Kutub al-'Alamiyah, |99|), 37.
} 
menunaikan haji ke Baitullah jika engkau telah mampu melakukannya." Lelaki itu berkata,"engkau benar," maka kami heran, ia yang bertanya ia pula yang membenarkannya." (Muslim).

Zakat bukan bertujuan untuk sekedar menggugurkan kewajiban sebagai seorang muslim, tapi tujuan utamanya adalah agar manusia lebih tinggi nilainya daripada harta, sehingga manusia menjadi tuannya harta bukan menjadikan budaknya. Dengan demikian kepentingan tujuan zakat terhadap si pemberi sama dengan kepentingannya terhadap si penerima. Beberapa dampak zakat bagi pemberi adalah untuk mensucikan jiwa dari sifat kikir, mendidik berinfaq dan memberi, merupakan manifestasi syukur atas Nikmat Allah, mengobati hati dari cinta dunia, mensucikan harta dari bercampurnya dengan hak orang lain, mengembangkan dan memberkahkan harta. ${ }^{24}$

Sedangkan dampak zakat bagi pemberi adalah untuk membebaskan si penerima dari kebutuhan, sehingga dapat merasa. hidup tenteram dan dapat meningkatkan kekhusyu'an beribadah kepada Tuhannya, dapat menghilangkan perbedaan antara orang kaya dan orang miskin, berfungsi untuk mengurangi para memintaminta, sebagai bantuan bencana dan mampu mengurangi jumlah pemuda-pemudi yang masih membujang.

Selain itu, ajaran Islam juga mengatur tentang hukuman bagi orang yang tidak melaksanakan (membayar) zakat, sebagaimana salah satu firman Allah SWT pada surat Ali-Imran ayat 180 dan surat al-Taubat ayat $34-35$, yakni :

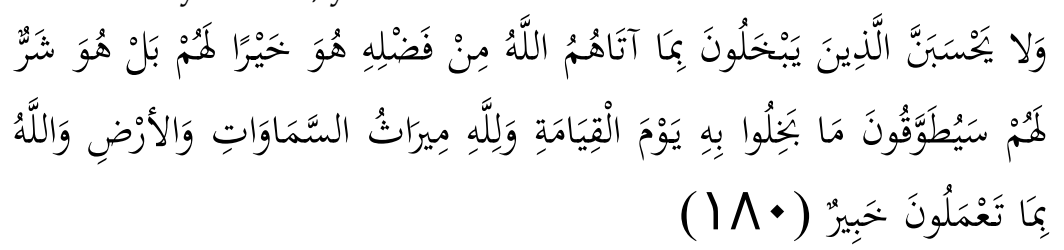

${ }^{24}$ Lukman Mohammad Baga, Sari Penting Kitab Fikih Zakat, Dr. Yusuf Al-Qaradhawy (New Zealand: University Palrmeston North, t.th), 4-5. 
"Sekali-kali janganlah orang-orang yang bakhil dengan harta yang Allah berikan kepada mereka dari karunia-Nya menyangka, bahwa kebakhilan itu baik bagi mereka. Sebenarnya kebakhilan itu adalah buruk bagi mereka. Harta yang mereka bakhilkan itu akan dikalungkan kelak di lehernya di hari kiamat. Dan kepunyaan Allahlah segala warisan (yang ada) di langit dan di bumi dan Allah mengetahui apa yang kamu kerjakan." (Ali-Imran : 180).

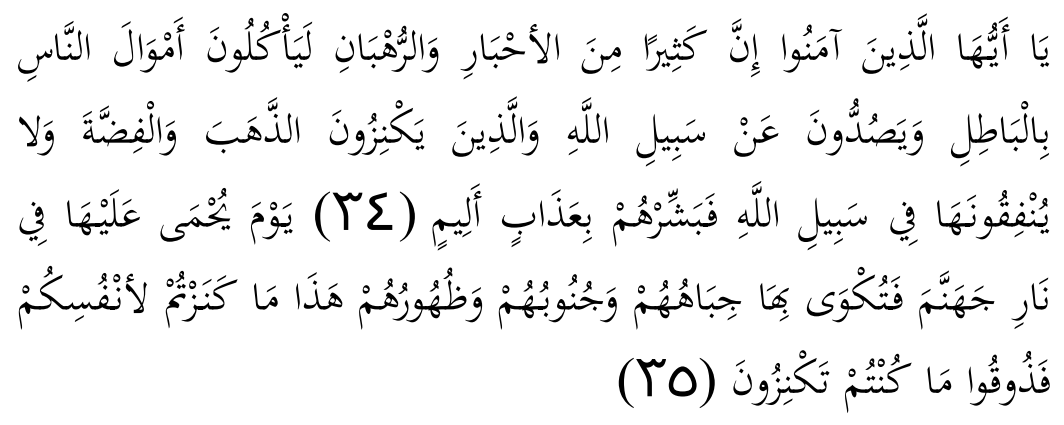

"Hai orang-orang yang beriman, sesungguhnya sebahagian besar dari orang-orang alim Yahudi dan rahib-rahib Nasrani benar-benar memakan harta orang dengan jalan batil dan mereka menghalanghalangi (manusia) dari jalan Allah dan orang-orang yang menyimpan emas dan perak dan tidak menafkahkannya pada jalan Allah, maka beritahukanlah kepada mereka, (bahwa mereka akan mendapat) siksa yang pedih. Pada hari dipanaskan emas perak itu dalam neraka Jahannam, lalu dibakar dengannya dahi mereka, lambung dan punggung mereka (lalu dikatakan) kepada mereka: "Inilah harta bendamu yang kamu simpan untuk dirimu sendiri, maka rasakanlah sekarang (akibat dari) apa yang kamu simpan itu." (Al-Taubah : 34-35)

Berdasarkan pembahasan di atas dapat dimengerti bahwa zakat adalah suat hal yang sangat asasi sekali dalam Islam dan hal inilah yang menjadi nilai-nilai intrinsik (inti) yang dianut bagi umat Islam dalam menunaikan zakat. 


\section{Penutup}

Regulasi Perda Tentang pengelolaan zakat di Kota Mojokerto secara garis besar hampir sama dan hanya terdapat sedikit perbedaan dengan Pengelolaan Zakat di Kabupaten Sidoarjo. Hal itu bisa dilihat dari persamaan pengertian, landasan, asas serta tujuan pengelolaan zakat. Begitu juga dengan unsur-unsur pada organisasi, tata kerja, obyek, ketentuan, pendayagunaan dan pelaporan, pembiayaan dan pengawasan serta ketentuan pidana pengelolaan zakat yang hanya memiliki sedikit perbedaan seperti perbedaan penggunaan nama istilah.

Proses pelaksanaan Perda Nomor 3 Tahun 2010 tentang Pengelolaan Zakat di Kota Mojokerto dilaksanakan dengan Peraturan Walikota Mojokerto Nomor 54 Tahun 2009 tentang Pedoman Teknis Pemungutan Zakat Pendapatan, Infaq dan Shodaqoh bagi PNS, karyawan BUMD/BUMN, anggota DPRD dan warga masyarakat Kota Mojokerto tahun 2009. Sedangkan Pelaksanaan Perda Nomor 4 Tahun 2005 tentang Pengelolaan Zakat di Kabupaten Sidoarjo belum menggunakan Peraturan Bupati, melainkan menggunakan Surat Edaran Bupati Nomor 400/2517/404.1.2/2008 tentang Pelaksanaan Pengumpulan Zakat, Infaq dan Shodaqoh. Dengan adanya Peraturan Walikota Mojokerto serta Surat Edaran Bupati Sidoarjo tersebut, pengelolaan zakat menjadi lebih efektif.

Perkembangan pengelolaan zakat pada BAZ di Kota Mojokerto dan Kabupaten Sidoarjo dengan adanya Perda tentang Pengelolaan Zakat menjadi lebih efektif. Hal itu bisa dilihat dari bertambahnya jumlah mudhakki, peningkatan perolehan dana zakat serta biaya operasional BAZ dibebankan kepada APBD. Perkembangan tersebut merupakan suatu bentuk ketaatan yang bersifat internalization atau suatu peraturan ditaati karena merasa bahwa aturan itu sesuai dengan nilai-nilai intrinsik (inti) yang dianut yakni nilai-nilai ajaran agama Islam. Akan tetapi, peningkatan kesejahteraan masyarakat tidak bisa dinilai secara 
menyeluruh karena BAZ masih memiliki halangan dan hambatan dalam mengelola zakat.

\section{Daftar Pustaka}

Abdillah, Masykuri. Formalisasi Syariat Islam di Indonesia. Ciputat: Renaisan, 2005.

Abdul Malik ar-Rahman, Muhammad. Zakat, 1001 Masalah dan Solusinya. Jakarta: Pustaka Cerdas Zakat, 2003.

Ali, Achmad. Menguak Teori Hukum (Legal Theory) dan Teori Peradilan (Judicialprudence). Jakarta: Prenada Media Group, 2009.

Buletin Al-Ashnaf BAZ Kota Mojokerto edisi 1, Mei 2011.

Buletin Al-Ashnaf BAZ Kota Mojokerto edisi 2, Agustus 2011.

Buletin Al-Ashnaf BAZ Kota Mojokerto edisi 3, Oktober 2011.

Buletin Al-Ashnaf BAZ Kota Mojokerto edisi 4, Januari 2012.

Buletin Al-Ashnaf BAZ Kota Mojokerto edisi 5, Triwulan I 2012.

Buletin Al-Ashnaf BAZ Kota Mojokerto edisi 6, Triwulan II 2012.

Buletin Al-Ashnaf BAZ Kota Mojokerto edisi 9, Triwulan I 2013.

Buletin Media komunikasi Umat BAZ Kabupaten Sidoarjo edisi XXIV Muharram $1434 \mathrm{H}$.

Buletin Media komunikasi Umat BAZ Kabupaten Sidoarjo edisi XXV Jumadil Awal $1434 \mathrm{H}$.

Grafik perolehan \& pendistribusian 2001-2012 \& rekapitulasi data pendistribusian bagi fakir miskin dan keluarga tidak mampu tahun 2012 BAZ Kabupaten Sidoarjo.

Imam Abu al-Husain Muslim bin al-Hajjaj al-Qushairiy alNaisaburiy. Sahih al-Muslim. Beirut: Dar al-Kutub al'Alamiyah, 1991.

Khasanah, Umrotul. Manajemen Zakat Modern, Instrumen Pemberdayaan Ekonomi Umat. Malang: UIN- Maliki Press, 2010.

Laporan pengumpulan dan Pendistribusian Rekapitulasi Data Pengumpulan ZIS BAZ Kabupaten Sidoarjo 2002-2011.

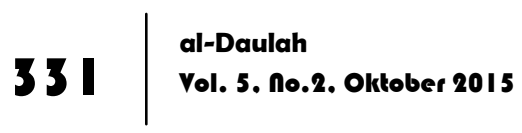


Laporan tahunan Badan Amil Zakat Kota Mojokerto tahun 2010. Laporan tahunan Badan Amil Zakat Kota Mojokerto tahun 2011. Laporan tahunan Badan Amil Zakat Kota Mojokerto tahun 2012. Naskah Akademik RANPERDA ZIS Kota Mojokerto.

Peraturan Daerah Kota Mojokerto Nomor 3 Tahun 2010 tentang Pengelolaan Zakat, Infaq dan Shodaqoh.

Peraturan Daerah Nomor 4 Tahun 2005 tentang Pengelolaan Zakat di Kabupaten Sidoarjo.

Peraturan Walikota Mojokerto nomor 54 tahun 2009.

Program Kerja BAZ Kabupaten Sidoarjo tahun 2007 s/d 2015.

Program Kerja BAZ Kota Mojokerto tahun 2010 s/d 2013.

Ridwan Mas'ud, Muhammad. Zakat \& Kemiskinan, Instrumen Pemberdayaan Ekonomi Umat. Yogyakarta: UII Press Yogyakarta, 2005.

Soeprapto, Maria Farida Indrati. Ilmu Perundang-Undangan, DasarDasar dan Pembentukannya. Yogyakarta: Penerbit Kanisius, 1998.

Undang-Undang Nomor 12 Tahun 2008 tentang Perubahan Kedua atas Undang-Undang Nomor 32 Tahun 2004.

Undang-Undang Nomor 12 Tahun 2011 tentang peraturan Pembentukan Perundang-undangan.

Undang-Undang Nomor 23 Tahun 2011 tentang Pengelolaan Zakat.

Undang-Undang Nomor 32 Tahun 2004 tentang Pemerintahan Daerah. 